\title{
Merkez Kütüphane Algılanan Hizmet Kalitesinin Uşak Üniversitesi Marka Farkındalığı Üzerindeki Rolüne İlişkin Bir Araştırma
}

\author{
Polat CAN*, Murat SEZGINN**
}

ÖZ

Hizmet işletmelerinin rekabette başarılı olabilmesi ve üstünlük sağlayabilmesi açısından algılanan hizmet kalitesinin yükseltilmesi ve buna bağlı olarak müşteri memnuniyetinin sağlanması önemlidir. Hizmet işletmeleri olarak kabul edilen kütüphanelerin, kullanıcılara uygun fiziksel ortamı sağlaması, güncel yayınları sunması ve çalışanlara güven sağlaması gibi önemli amaçları bulunmaktadır. Bu çalışmanın amacı kütüphane hizmetlerinde algılanan kalitenin Uşak Üniversitesi'nin marka farkındalığı üzerindeki rolünü tespit etmektir. Bu amaç doğrultusunda Uşak Üniversitesi Bir Eylül Kampüsü'nde öğrencilere anket uygulaması yapılmış ve kütüphane hizmet kalitesi ve üniversitenin marka farkındalığı ile igili ifadeleri değerlendirmeleri istenmiştir. Elde edilen veriler SPSS 18 paket programı ile analiz edilmiştir. Verilerin analizinde ortalama, frekans dağılımı, korelasyon analizi ve kanonik korelasyon kullanılmıştır. Yapılan bu analizlerin sonucunda algılanan hizmet kalitesi boyutları ile marka farkındalığı arasında anlamlı bir ilişkinin olduğu tespit edilmiştir.

Anahtar Kelimeler: Hizmet Pazarlaması, Algılanan Hizmet Kalitesi, Marka Farkındalığı, Kütüphane.

JEL Sınıflandırması: M31.

\section{A Survey on the Role of Central Library Perceived Service Quality on Uşak University Brand Awareness}

\begin{abstract}
Improving service quality and ensuring consumer satisfaction correspondingly are important for service businesses to be successful and put in excellent performance. Accepted as a service businesses, libraries have such important purposes as providing suitable physical environment, updated journals and employees trust. The purpose of this study is to determine the role of perceived quality in library services on Uşak University brand awareness. In accordance with this purpose, a survey for students at Uşak University Bir Eylül Campus has been conducted and they have been requested to evaluate the terms regarding library service quality and brand awareness of the university. The acquired data were analysed with SPSS 18. In the analyses of acquired data, average, frequency distribution, correlation analysis and canonical correlation have been used. As a result of these analyses, it has been determined that there is an significant relationship between service quality dimenions and brand awareness.
\end{abstract}

Keywords: Service Marketing, Perceived Service Quality, Brand Awareness, Library.

JEL Classification: M31.

Geliş Tarihi / Received: 15.06.2016 Kabul Tarihi / Accepted: 26.06.2016

\footnotetext{
*Yrd.Doç.Dr., Uşak Üniversitesi, İletişim Fakültesi, Halkla İlişkiler ve Reklamcılık Bölümü, polat.can@usak.edu.tr

*** Doç.Dr., Uşak Üniversitesi, İletişim Fakültesi, Halkla İlişkiler ve Reklamcılık Bölümü, murat.sezgin@usak.edu.tr
} 


\section{GİRIŞ}

Günümüzün küreselleșen pazarında yaşanan ekonomik değişimler ve buna bağlı olarak sanayileşmenin hızlanması hizmet kavramının önemini arttırmaktadır. Bu durumun başlıca sebepleri, hizmetlerin fiziksel malları tamamlayan unsur olması, refah ve gelişmişlik düzeyinin göstergesi olması, teknolojinin hızla gelişmesi ve tüketici isteklerinde yaşanan değişimlerin farklı hizmet türlerini ortaya çıkarmasıdır. Dünyadaki bu gelişmelere paralel olarak hizmet sektörünün önemi ülkemizde de son yıllarda artmaktadır. Ulaşım, bankacılık, sağlık, turizm, eğitim gibi alanlarda yaşanan değişim, bu alanlarla ilgili hizmet çeşitlerini ve bu sektörde faaliyet gösteren işletmelerin sayısının artmasına neden olmaktadır. Ülkemizde ise, 1990'lı yıllarda itibaren hizmet sektörü hızlı bir büyüme göstermektedir.

Hizmet sektörlerindeki gelişmeyle birlikte eğitim sektöründe önemli yere sahip olan yükseköğretim kurumları da büyümektedir. Bütün sektörlerde olduğu gibi eğitim alanındaki önemli konulardan biri de, potansiyel alıcıların dikkatini çekip tercih etmesini sağlamaktır. Bunun sağlanması için öncelikle önem verilmesi gereken hususlarda biri algılanan hizmet kalitesini tespit etmektir. Günümüzde yükseköğretim kurumları algılanan hizmet kalitelerini yükseltmek için rakiplerinden daha etkin ve başarılı hizmet sistemi oluşturmaya çalışmaktadır.

Üniversiteler eğitim hizmeti üreten kurumlardan biridir. Üniversiteler günümüzde hem kendi aralarında hem de uluslararası alanda güçlü rakiplere sahiptir. Hizmet kalitesini sürekli iyileştirmek zorunda olan üniversiteler bu yoğun rekabette öne çıkmak ve lider durma gelmek için markalaşmaya önem vermektedirler. Bu sektörde tüketici tekrarlanan satın alım yapmadığ için markalaşmak ise üniversiteyi başkalarına tavsiye etmek, üniversitenin işaret ve logosuna sahip ürünleri satın almak ve mezunlar derneklerine üye olmak gibi etkinliklerle sağlanmaktadır. Markalaşmanın oluşması, kaliteli öğretim üyelerine sahip olmanın yanında, altyapı hizmetlerinin de kalite anlayışı çerçevesinde düzenlenmesini gerekmektedir. Bunlar; öğrencilerin yemek, barınma, güvenlik, temizlik gibi zorunlu ihtiyaçları, sosyalleşme ihtiyaçları, geleceklerini şekillendirme ihtiyaçlarını içeren kütüphane hizmetleri ve bu hizmetlerin gerçekleştirilmesini sağlayacak altyapılar olarak ifade edilmektedir.

Hizmet kalitesinin ölçülmesinde SERVQUAL Ölçeği en fazla tercih edilen yöntemlerin başında gelmektedir. Ancak bu kadar çok kullanılmasına rağmen çok fazla eleştiriye de maruz kalmaktadır. Bu eleştirilerin büyük kısmı, SERVQUAL'in hizmet kalitesini algılama-beklenti farkını temel alarak ölçmesine yöneliktir. Bu eleştiriler nedeniyle, özellikle son zamanlarda yapılan çalışmalarda hizmet kalitesinin ölçümü algılanan ve beklenen arasındaki fark yerine yalnızca algılamaya (performansa) dayalı olarak yapılmaktadır. Bu doğrultuda çalışmamızda benzer ölçüm yöntemi tercih edilmiştir.

\section{TEORÍK ÇERÇEVE}

\subsection{Hizmet ve Kalite Kavramları}

Günümüzde hizmet kavramının önemi bütün sektörlerde giderek artmaktadır. Hizmetler, kuaför salonlarında verilen hizmet etkinliklerinden, ulaşım işletmelerinin hizmetlerine kadar farklı alanlara yayılmış, çeşitli heterojen faaliyetleri içermektedir. Örneğin, hizmetin kapsamına; fikir, eğlence, bilişim, eğitim, reklam, turizm ve güvenlik gibi benzer şeyler girebilmektedir. Bu yüzden, hizmet kavramı oldukça karışık ve tanımlanması zor bir kavramdır (Parasuraman, 2002:7).

Hizmet, tüketici istek ve beklentisini karşılamak amacıyla üretilen ve fiziksel olmayan üründür (Kuriloff ve diğ., 1993:247). Hizmet, fiziksel ve psikolojik olarak tüketiciye, sosyal boyutuyla da topluma zaman ve yer faydası sağlayan ürün olarak tanımlanabilir (Devebakan, 2005:7). Hizmet, dokunulmaz yapıya sahip, tüketici ve hizmet personeli arasındaki etkileşim ile sunulan ve tüketici sorunlarına çözüm önerileri sağlayan süreç dizisidir (Grönross, 2000:46). 
Hizmet, fiziksel olmayan, bireyin hareketi ile ortaya konulan faaliyettir. Bu açıdan hizmete olan talep saatlik, günlük ve mevsimlik olarak değişebildiğinden arz ve talebi dengelemek kolay olmamaktadır (Yapraklı ve Sağlık, 2010).

Yukarıda bahsedildiği gibi hizmetin net ve belirli bir tanımının yapılması ve kapsamının belirlenmesi zor olmaktadır. Bu yüzden toplum yapısının ve ekonomik durumun değişmesi ile birlikte teknolojik yeniliklere bağlı olarak, yeni ve farklı hizmet çeşitleri ortaya çıkmakta veya mevcut hizmetlerde farklılaşma görülmektedir. Bu yüzden ayrıntılı ve kapsamlı hizmet kavramını tanımlamak ve onu uzun süre değişmeden korumak mümkün olmamaktadır (Kang, 2006:41). Ancak hizmet kavramı hakkında yapılan tanımlar 1şığında hizmet şu şekilde tanımlanabilir. Hizmet, tüketicinin ihtiyaç ve gereksinimlerini karşılamak amacıyla, belirli bedel karşıllğı satışa sunulabilen, üretilmesi fiziksel bir ürüne bağlı olan veya olmayan, üretimi ile tüketimi eşzamanlı olan, sunumuna tüketicinin katılımını gerektiren, fiziksel bir varlığa sahip olmayan, elle tutulamayan, taşınamayan, stoklanamayan, fiziksel sahiplik ile sonuçlanmayan, ihtiyaç karşılamak ve fayda elde etmek amacıyla üretilen soyut ürünlerdir (Meng ve diğ., 2009:776).

Hizmetin, fiziksel ürünlerden faklı olmasını sağlayan temel özellik dokunulamaz olmasıdır. Ayrıca ayrılmazlık, soyutluk ve dayanıklı olmama hizmetin özellikleri arasında sayılabilmektedir. İlave olarak, eylem ya da eylemler bütününü içeren süreç olması, eş zamanlı olarak üretilmesi ve tüketilmesi, tüketicinin üretim sürecinde aktif rol alması hizmetlerin diğer özellikleri arasında yer almaktadır (Bebko, 2000:9).

Hizmetin hem kendine özgü sektörlere sahip olması hem de fiziksel mal üretilen sektörlerde önemli faktörlerin başında gelmesi, tüketici istek ve beklentilerini karşılama yeteneğini gündeme getirmekte ve buna bağlı olarak da kalite kavramını ortaya çıkarmaktadır. Günümüz şartlarında kalite, işletme için pazarda önemli rekabet unsuru ve tüketici açısından ise tercih sebebi olmaktadır. Çünkü işletmelerin pazarda mevcudiyetlerini sürdürebilmesi için rakiplerinden farklı olması gerekmektedir. Ancak bu farklılık sayesinde işletmeler tüketicinin beğeni ve güvenini kazanılabilmektedir. Bu bağlamda tüketici isteklerini anlayan, düşük maliyetle kaliteli ürün ve hizmetleri pazara sunabilen işletmeler pazarda kalıcı olabilmektedir (Sahney ve diğ., 2004:146).

Kalite, Latince nasıl oluştuğu anlamına gelen 'qualis' kelimesinden gelmektedir. Günümüzdeki anlamıyla sözcük, ürün ve hizmetlerin ne olduğunu vurgulamak ve belli etmek amacıyla kullanılmaktadır. Kalite çok boyutlu bir kavram olduğu için, herkesin genel olarak üzerinde anlaşabileceği bir kalite tanımı yapmak zor olmaktadır (Güzel ve Kotan, 2013:12).

Kalite, müşteri memnuniyeti ve rekabet üstünlüğü sağlamak için işletmeler açısından pazarda devamlı olabilmek için önemli bir kavramdır (Morgan ve Vorhies, 2001:399). Bu bakımdan kalite, farklı bakış açılarından ele alınarak incelenmiş ve tanımlanmıştır. Kalite, sadece tüketici istek ve beklentisinin karşılanması değil bunların ötesinde tüketici memnuniyetini sağlayan önemli bir rekabet aracıdır (Calantone ve diğ., 2010:351). K1sacas1 kalite, ürünün tüketici ihtiyaç, beklenti ve isteğine uygunluğudur (Fuchs ve Schreier, 2011:26). Kalite; pazarlama ve üretim sistemlerinin kullanılarak tüketicinin beklentilerini karşılama kabiliyeti olan ürün özelliklerinin bütünü olarak tanımlanabilir. Son olarak kalite, ürünün ekonomik ve kullanış açısından tasarlanması, üretilmesi ve pazara sunumudur (Schmidt ve Druehl, 2008:351).

Yukarıdaki tanımların tamamı dikkate alındığında kaliteyi hataları en düşük seviyeye indirme ya da standartlara uyum olarak ürün odaklı tanımlayan yaklaşımlarla, müşteriyi odak noktasına alan tanımlar görülmektedir. Her iki bakış açısı da dikkate alındığında, kalite kavramı genellikle kullanım amacına uygunluk olarak tanımlanmaktadır. Bu bağlamda ürün özelliklerinin 
farklılaşmasından dolayı hizmetler için ayrı dikkate alınması gereken bir kavramdır. Dolayısıyla hizmet kalitesi kavramı bir sonraki bölümde ele alınması gerekmektedir.

\subsection{Hizmet Kalitesi}

Hizmetlerin, fiziksel ürünlerden farklılıkları dikkate alındığında fiziksel ürünler için yapılan kalite tanımının hizmetler için yetersiz kaldığı görülmektedir. Günümüzde kalite kavramının öneminin artması, hizmet kalitesi çalışmalarının çok fazla araştırılmasına neden olmaktadır. Çünkü işletmeler hizmetlerinin kalitesini arttırarak pazar paylarını büyütebilmekte, yüksek karlılık ve verimlilik sağlamakta, tüketici bağlılığı oluşturabilmekte ve bunun sonucunda rakiplerine karşı avantaj sağlayabilmektedirler (Mei ve diğ.,1998:138).

Hizmet kalitesi ile ilgili yapılan çalışmalar incelendiğinde, sektöre ve sunulan hizmetin özelliğine bağlı olarak çok sayıda ve birbirlerinden farklı tanımların yapıldığı görülmektedir. Bu tanımlarda genel olarak hizmet kalitesi; "müşteri beklentilerinin karşılanması için, üstün ya da mükemmel hizmetin verilmesi" olarak belirtilmektedir (Uyguç, 1998:26). Bir başka tanımda hizmet kalitesi "hizmeti alanın beklentilerinin en iyi şekilde karşılanması" şeklinde ifade edilmektedir (Odabaş1, 2003:93). Parasuraman ve diğ. ise "hizmeti alanın beklentisi ve algıs1 arasında ki fark" olarak tanımlamaktadır (Parasuraman ve diğ, 2008:12). Bu bakımdan tüketici, hizmet kalitesini değerlendirirken, beklentisi ile gerçekleşen hizmeti karşılaştırarak karar vermektedir. Bu bağlamda, işletmeler yüksek kaliteli hizmet sundukça pazar payları artmakta ve bunun sonucunda rekabette rakiplerinden önde olmakta, uzun dönemde karları artmakta ve pazarda kalıcı olabilmektedirler (Zengin ve Erdal, 2005:4). Hizmet kalitesi kavramını daha iyi anlamak için "beklenen hizmet kalitesi ve algılanan hizmet kalitesi" ni ele almak gerekmektedir.

Beklenen Hizmet Kalitesi: Tüketicinin, hizmetten istek ve beklentisini karşılamak için hizmette bulunmak istediği özellikleri kapsamaktadır. Bu kavram, tüketicinin sunulan hizmetten memnun kalıp kalmaması ve beklentisinin gerçekleşip gerçekleşmemesi ile ilgilidir. Beklenti kavramı, tüketici memnuniyeti kavramdan oldukça farklıdır. Çünkü, tüketici tatmini boyutunda beklenti; tüketicinin satın alımı esnasında gerçekleşmesi muhtemel olan şeylerle ilgili yapılan tahminler olarak kabul edilmektedir. Diğer açıdan beklenti, tüketici istek ya da ihtiyacı olarak ele alınmaktadır (Hacıefendioğlu ve Koç, 2009:148).

İşletmelerin beklenen hizmet kalitesinin kapsamını belirlemesi ve bu konuda standart özellikler tespit etmesi zor olmaktadır. Ancak işletmeler tüketicinin hizmetten beklentisi ile ilgili olarak çeşitli tahminler yürütebilmektedir. Örneğin; kütüphaneye gelen her öğrencinin ihtiyac1 farklı olduğu için kütüphaneden beklediği hizmet de diğer öğrencilerden farklılık göstermektedir. Tüketicinin beklentisini doğru tahmin edebilen ve bu doğrultuda hizmet sağlamaya çalışan işletmeler, daha fazla tercih edilmekte ve rakipleri ile arasındaki farklılık kolaylıkla görülebilmektedir (Naik ve diğ., 2010:231).

Algllanan Hizmet Kalitesi: Tüketicinin hizmeti almadan önceki beklentisi (beklenti) ile satın aldığı hizmeti karşılaştırmasının sonucudur. Bu bağlamda algılanan hizmet kalitesi tüketicinin beklentisi ile algıladığı performans arasındaki farklılığın yönü ve derecesi olarak tanımlanabilir. Hizmet kalitesinde "beklenti" kavramı ise tüketicinin hizmetle ilgili istek ya da arzusunu ifade etmektedir (Yanık ve diğ., 2012:597). Bir başka tanımda algılanan hizmet kalitesi, "tüketicinin mükemmel veya ideallere dayanan beklentileri ile işletmenin algılanan performansını karşılaştırılması sonucunda ortaya çıkan global bir değerlendirme olarak" tanımlamaktadır (Nakip ve diğ., 2005:375).

Algılanan hizmet kalitesi, tüketicinin satın alımlarında ürün hakkında sahip olduğu duygu ve düşüncelerini etkilemektedir. Bu tüketiciyi etkileme aşamasında, önemli faktörlerin başında işletme çalışanları yani hizmeti sunan personel gelmektedir. Çünkü hizmeti sunanların davranışlarının tüketicinin hizmet kalitesini algılamasında önemli etkileri vardır (Tsaur ve Lin, 2004:472). Günümüzde çoğu işletme, olumlu hizmet kalitesi algısını geliştirmek için 
çalışanlarından birç̧ok ilave rol ve davranış göstermesini istemektedir. Örneğin, çağrı merkezi çalışanlarından tüketiciye ismiyle hitap etmesi ve telefonu ilk çalışta açması istenmektedir (Avcı ve Sayılır, 2006:124).

Algılanan hizmet kalitesinin oluşturulmasında çoğu zaman fiziki imkanlar, güvenirlik, uygun zaman, tüketiciyle karşı1ıklı iletişim gibi hususlar etkili olmaktadır. Bu faktörlerden, doğru ve güvenilir hizmetin, kısmen hizmeti sunanlara ait olduğu söylenebilir (Demirel, Yoldaş, Divanolu, 2009:3-4). Çünkü, tüketicinin kaliteyi tanımlaması, hizmeti tüketim deneyiminden algıladığı histir. Tüketicinin hizmet kalite algılaması, tüketim gerçekleştikten sonraki hizmet ile ilgili düşünceleridir. $\mathrm{Bu}$ bağlamda çalışanların davranış ve tutumları algılanan kalitenin tüketiciden tüketiciye farklılık göstermesine neden olabilmektedir. Ayrıca bu farklılık, tüketicinin önceliği, değeri, eğitim seviyesi, kültürü, yaşı, cinsiyeti gibi birçok demografik faktörden etkilenmektedir (Tekingündüz, 2010:542).

\subsection{Kütüphane Hizmet Kalitesi}

Kütüphaneler, bilgiyi üretenle tüketen arasında bilgi alış verişini sağlayan bilgi araç ve merkezleri olarak faaliyet göstermektedir. Toplumun bilinçlenmesi, bireylerin bilgi ve kültür düzeylerinin artmasında kütüphaneler büyük önem taşımaktadır. Ayrıca, okuma, analitik düşünme ve araştırma alışkanlığının kazandırılması kütüphaneler aracılığı ile olmaktadır. Akademik araştırmaların temelini oluşturan bilgi elde etme ve araştırma yapma çoğunlukla kütüphaneler yardımıyla gerçekleşmektedir. $\mathrm{Bu}$ bağlamda, demokratik toplumlarda kütüphaneler, özgür düşüncenin oluşturulması, eğitim temelinin sağlanması, toplumun kültür seviyesinin gelişmesi ve bilinçlenmesi açısından büyük sorumluluklar taşımaktadır (Güzel ve Kotan, 2013:13).

Üniversitelerde kütüphaneler, eğitim, öğretim ve araştırma ihtiyacını karşılamak için oluşturulan hizmet birimlerdir. Bağlı bulunduğu üniversitenin bünyesine ve amacına göre farklı yapılara sahiptirler. Uşak Üniversitesi Kütüphanesi'nin amacı; akademisyen ve öğrencilerin istediği bilgi ve belgeyi sağlamak ve sağlanan bilgi ve belgeleri kullanıma sunulacak şekilde düzenlemektir. Bir başka amacı ise, mevcut bilgi kaynaklarından uygun biçimde yararlanmak için her seviyedeki kullanıcının yararlanacağı şekilde üniversite içi ve dışı hizmet vermektir. Bu amaç doğrultusunda kullanıcılarına görsel, işitsel malzeme temin etme, kitap ödünç verme, koleksiyon geliştirme, tanıtım, eğitim faaliyetleri, programlama ve danışmanlık hizmetleri gibi işlevleri yerine getirmektedir.

Geleneksel olarak, akademik kütüphanelerin kalitesi hakkında değerlendirme, sahip oldukları malzeme ve materyalin sayıs1 ile yapılmaktadır. $\mathrm{Bu}$ sebepten üniversite kütüphanelerinin çoğunluğu malzeme ve materyallerinin sayıca arttırılması üzerinde odaklanmaktadır (Sharma, 2001:169). Ancak günümüzde modern kütüphanecilik anlayışında hizmet kalitesi olarak hızlı teslimat, hatasız sorun çözme, güncel verilere ulaşma ve uygun çalışma ortamlarının oluşturulması gibi faktörler kütüphane hizmet kalitesi faktörleri olarak kabul edilmektedir. $\mathrm{Bu}$ faktörlerin yerine getirilmesi üniversitenin imajına olumlu katk1 sağlamakta ve bu durum üniversitenin markalaşmasını sağlamaktadır (Jamali ve Tooranloo, 2009:320).

\section{4. Üniversitelerde Markalaşma}

Günümüzde yükseköğretim kurumları birer işletme gibi davranmakta ve hizmet sektöründeki işletmeler gibi markalaşma ve itibar yönetimi konularına önem vermektedir. $\mathrm{Bu}$ bağlamda, üniversitelerin markalaşma nedenleri arasında, potansiyel öğrencilerin ve ailelerinin dikkatinin çekilmesi ve onlarla iletişime geçilmesi yer almaktadır (Brookes, 2003:136). Bulotaite (2003) üniversite isminden bahsedildiğinde akla imaj, çalışanlar ve deneyimlere ilişsin hususların geldiğini, bu sebeple üniversitelerin de markalaşmasının önemli olduğunu savunmaktadır (Nardalı ve Tanyeri, 2011:310). Üniversitelerde markalaşma, diğer 
üniversitelerden farklı olan yanların ortaya konması, öğrencilerin ihtiyaçlarının karşılanmasında mevcut imkanların gösterilmesi, eğitim imkanları bakımından güven oluşturulması ile başarılı öğrencilerin üniversiteye yönelik ilgisinin artırılması şeklinde tanımlanmaktadır (Bennett ve AliChouldry, 2007:29).

Tanınmış bir markaya sahip olan üniversitenin, sınav sonuçlarında üst sıralarda yer alan daha fazla öğrencinin ilgisini çekmekte, medyanın o üniversiteye yönelik ilgisi artmakta ve bunun sonucunda devlet bütçesinden daha fazla pay alabilmektedir (Nardalı ve Tanyeri, 2011:313). Üniversitelerin markalaşma nedenleri arasında, okul ücretleri ve rekabette farklılaşma ihtiyacının olması, üniversitelerin çeşitli kriterlere göre sıralanması, vakıf üniversitelerinin sayısının artması ve üniversiteye yönelik yanlış düşüncelerin önlenmesi olarak siralanmaktadır (Stamp, 2004:7).

Marka sadakati rakibin pazarlama faaliyetlerinin etkinliğine rağmen, tüketicinin ayn markayı sonraki satın alımlarında tercih etmesi olarak tanımlanmaktadır (Oliver, 1999:36). Üniversite markası ile ilgili sadakat kavramı ise eğitim çoğunlukla bir kez alındığı için, marka bağl1lı̆̆ kapsamında tekrarlanan satın alım olmamaktadır. Ancak ürünün tekrar satın alınmamasına rağmen üniversite marka bağlılığı kapsamında ilgili üniversite logolu kıyafetlerin giyilmesi, üniversitenin mezun gruplarına üye olunması, üniversitenin diğer bireylere tavsiye edilmesi yükseköğretim kurumlarında markalaşmanın göstergesi olmaktadır (Liu ve ShengHua, 2008: 47).

Üniversitede verilen eğitimin yanında öğrencilere sunulan araştırma imkânları, derslik ve laboratuarların uygun ve ekipmanlarının yeni olması markalaşmada öne çıkan konular arasında yer almaktadır. Ek olarak öğrencilerin üniversitede sosyal faaliyetleri için uygun alan ve tesislerin olması kampüs içerisinde güzel zamanların geçirilmesini sağlamakta ve bu durum kurumun markalaşmasında önemli rol oynamaktadır. Bu açıdan üniversite yönetimi tarafından eğitime yönelmekle birlikte öğrencinin ilgisini çekecek aktivitelerle dolu eğitim programının geliştirilmesi gerekmektedir. $\mathrm{Bu}$ tür sosyal aktiviteler öğrencilerin birbirlerini daha fazla tanımalarını sağlamakta ve birbirleri ile dayanışmayı geliştirmektedir. Unutulmaması gerekn husus ise bu etkinliklerde üniversite gelenek ve görenekleri mutlaka vurgulanmalıdır (Nardalı ve Tanyeri, 2011:314).

\section{ALGILANAN KÜTÜPHANE HIZMET KALITESININ UŞAK ÜNIVERSITESİ MARKA FARKINDALIĞI ÜZERİNDEKİ ROLÜNE İLİSTKİN BİR ARAŞTIRMA}

\subsection{Araştırmanın Amacı, Kapsamı ve Kısıtları}

Kütüphanelerde memnuniyet, kullanıcının aldığı hizmetin kalitesi ile doğru orantılı olduğu için algılanan hizmet kalitesi kütüphane uygulamalarının değerlendirilmesinde önemli unsurların başında gelmektedir. $\mathrm{Bu}$ bağlamda araştırmanın öncelikli amacı kullanıcıların algılanan hizmet kalitesine yönelik duygu ve düşüncelerini tespit etmektir. Çalışmanın ikinci amac1 ise kütüphanenin sunduğu hizmetlerin kalitesinin üniversitenin marka farkındalığına etkisindeki rolünü belirlemektir.

Merkez Kütüphane Uşak Üniversitesi Bir Eylül Kampusu'nde bulunduğu için araştırmanın kapsamına, yerleşke içerisinde bulunan İktisadi ve İdari Bilimler Fakültesi, Eğitim Fakültesi, Fen Edebiyat Fakültesi, Mühendislik Fakültesi, İslami İlimler Fakültesi, Ziraat ve Doğa Bilimleri Fakültesi, İletişim Fakültesi ve Spor Bilimleri Fakültesi, Uygulamalı Bilimler Yüksekokulu, Adalet Meslek Yüksekokulu, Teknik ve Sosyal Bilimler Meslek Yüksekokulu öğrencileri alınmıştır. Diğer yerleşkelerdeki yüksekokul ve meslek yüksekokulları araştırma kapsamının dışında tutulmuştur. Araştırmanın uygulaması Uşak Üniversitesinde gerçekleştirildiği için diğer özel ve kamu üniversitelerine genellenemez. 


\subsection{Araştırmanın Modeli}

Araştırmada birinci grup değişken olan algılanan hizmet kalitesinin ölçümünde Parasuraman, Zeithalm ve Berry (1985) tarafindan geliştirilen "Servqual Hizmet Kalitesi Ölçeği" nin algılanan hizmet kalitesi bölümü kullanılmıştır. İkinci grup değişken olan marka farkındalığı ise, Yoo ve Donthu (2001) ile Berry (2000)'nin çalışmalarından oluşturulmuştur. Ayrıca modelde demografik ve ekonomik değişkenler ile algılanan hizmet kalitesi arasında ilişki olabileceği varsayılmaktadır. Araştırmanın modeli Şekil 1'de verilmiştir.

Araştırmanın modelinde üç ana değişken yer almaktadır. Bu ana değiş̧kenlerden algılanan hizmet kalitesi 5 boyuttan oluşmaktadır. Fiziksel özellikler boyutu 4 ifade, güvenilirlik boyutu 5 ifade, heveslilik 4 ifade, güven 4 ifade ve empati boyutu 5 ifadedir. Algilanan hizmet kalitesi değişkeni toplam 22 ifade ve marka farkındalığı 6 ifadeden oluşmaktadır. Demografik ve ekonomik özellikler ise cinsiyet, yaş, gelir, eğitim görülen sınıf ve okul değişkenlerinden meydana gelmektedir. Dolayısıyla model 3 temel, 33 alt değişkenden müteşekkildir.

\begin{tabular}{|c|c|c|}
\hline Demografik ve & Alglanan & \\
\hline$\frac{\text { Ekonomik Özellikler }}{\text {-Cinsiyet }}$ & $\frac{\text { Hizmet Kalitesi }}{\text {-Fiziksel Özellikler }}$ & Marka \\
\hline \begin{tabular}{|l}
-Yaş \\
-Gelir \\
-Sinıf \\
-Okul türü
\end{tabular} & \begin{tabular}{|l}
-Güvenilirlik \\
-Heveslilik \\
-Güven \\
-Empati
\end{tabular} & Farkındalığı \\
\hline
\end{tabular}

Şekil 1: Araştırmanın Modeli

\subsection{Araştırmanın Hipotezleri}

Araştırmanın amacı ve modeli doğrultusunda aşağıdaki hipotez geliştirilmiştir.

H1: Algılanan hizmet kalitesi ile marka farkındalığı arasında anlamlı bir ilişki vardır.

\subsection{Araştırmanın Metodolojisi}

\subsection{1. Örnekleme Süreci}

Araştırmanın kapsamına Uşak Üniversitesi Bir Eylül Kampusu'ndaki fakülte, yüksekokul ve meslek yüksekokullarındaki öğrenciler alınmış ve ana kütlenin toplam 15224 ögrenciden oluşmuş olması örneklemin bu sayıya göre alınmasını süre ve maliyet bakımından zorlaştırmaktadır. Bu nedenle $\% 95$ güven aralığında $\% 5$ hata payı ile örneklem büyüklügü 384 olarak belirlenmiştir. Hatalı ve eksik doldurulması muhtemel anket olabileceği düşünülerek toplam 400 anket uygulanmıştır. Anketler fakülte, yüksekokul ve meslek yüksekokullardaki öğrenci sayılarına uygun oranda uygulanmıştır. Anket çalışması 2015-2016 akademik yılı Bahar yarıyılında 04-20 Mayıs 2016 tarihleri arasında yapılmıştır. Toplam 400 anket uygulanmış, eksik ve hatalı doldurulan anketlerin elenmesi sonucu 384 anket değerlemeye alınmıştır.

\subsection{2. Ön Çalışma}

Araştırma için kesin anket formu hazırlanıp veri toplanmasına geçilmeden önce araştırma örneğini temsil edecek şekilde seçilen 20 öğrenci ile ön anket çalışması yapılmıştır. Bu kişilere Uşak Üniversitesi Merkez Kütüphanesinin hizmetleri hakkında alg1 düzeylerini belirlemek için sorular sorulmuştur. İkinci aşamada ise Uşak Üniversitesi marka farkındalığı hakkında çeşitli ifadeler sorulmuştur. Seçilen öğrencilerin ilgili ifadeleri değerlendirmeleri sonucunda anlaşılmayan, yanlış anlaşılan ve karıştırılan ifadeleri belirtmeleri istenmiştir. Anket formu bu değerlendirmelerden sonra tekrar test edilmiş ve forma son şekli verilmiştir. 


\subsubsection{Veri Toplama Yöntem ve Aracı}

Araştırmada veriler, kapalı uçlu soruların yer aldığı anket yöntemi kullanılarak toplanmıştır. Anket formunda 3 grup soru yer almıştır. 1. grupta cevaplayıcıların üniversite kütüphanesinin hizmetlerini algılama seviyelerini belirlemek amacıyla çeşitli ifadeler sunulmuştur. 2. grup demografik ve ekonomik özellikleri sorularından oluşmuş ve 3. grup sorular ise cevaplayıcıların Uşak Üniversitesi'nin marka farkındalığına yönelik yargılarını tespit etmek amacıyla hazırlanmıştır. Modelde yer alan algılanan hizmet kalitesi değişkenleri Servqual Hizmet Kalitesi Ölçeğinden yararlanılarak hazırlanmıştır. Marka farkındalığını ölçmek üzere 6 ifadeden oluşan bir ölçek kullanılmıştır. Ölçek hazırlanırken Yoo ve Donthu (2001), Berry (2000)'in kullandığı ölçeklerden yararlanılmıştır. Cevaplayıcıların algılanan hizmet kalitesi ve marka farkındalığı ile ilgili yargılara katılma derecesi 5'li likert ölçeği (5=Tamamen katılıyorum, $1=$ Kesinlikle katılmıyorum) ile ölçülmüştür.

Verilerin analizinde SPSS 18.0 paket istatistik programı kullanılmıştır. Araştırmada ortalamalar, standart sapma, frekans dağılımları, Kendall korelasyonu ve kanonik korelasyon analizleri yapılmıştır.

\subsection{Verilerin Analizi}

\subsubsection{Demografik ve Ekonomik Özellikleri}

Tablo 1'de ankete katılan cevaplayıcıların demografik ve ekonomik özellikleri sunulmuştur.

Tablo 1: Cevaplayıcıların Demografik ve Ekonomik Özellikleri

\begin{tabular}{|c|c|c|c|c|c|}
\hline Cinsiyet & Frekans & Yüzde & $\begin{array}{l}\text { Eŭitim Gördüğü } \\
\text { Sınıf }\end{array}$ & Frekans & Yüzde \\
\hline $\mathrm{K}_{1 \mathrm{Z}}$ & 201 & 52,3 & Birinci Sinıf & 232 & 60,4 \\
\hline Erkek & 183 & 47,7 & İkinci Sınıf & 77 & 20,0 \\
\hline Yaş & Frekans & Yüzde & Üçüncü Sınıf & 49 & 12,8 \\
\hline 18 ve alt 1 & 16 & 4,2 & Dördüncü Sınıf & 26 & 6,8 \\
\hline 19 & 98 & 25,5 & $\begin{array}{l}\text { Eğitim } \\
\text { Okul }\end{array}$ & Frekans & Yüzde \\
\hline 20 & 107 & 27,8 & Eğitim Fak. & 48 & 12,5 \\
\hline 21 & 81 & 21,0 & İ̈BF & 86 & 22,4 \\
\hline 22 & 39 & 10,2 & Fen Edebiyat Fak. & 81 & 21,1 \\
\hline 23 & 27 & 7,1 & Güzel Sanatlar Fak. & 4 & 1,0 \\
\hline 24 ve üzeri & 16 & 4,2 & İslami İlimler Fak. & 14 & 3,6 \\
\hline Gelir (TL) & Frekans & Yüzde & İletişim Fak. & 10 & 2,6 \\
\hline $0-300$ & 109 & 28,3 & Mühendislik Fak. & 39 & 10,2 \\
\hline
\end{tabular}




\begin{tabular}{|l|c|l|l|c|c|}
\hline $301-600$ & 190 & 49,5 & Spor Bilimleri Fak. & 5 & 1,3 \\
\hline $601-900$ & 64 & 16,7 & $\begin{array}{l}\text { Ziraat ve Doğa Bil. } \\
\text { Fak. }\end{array}$ & $\begin{array}{l}\text { Uygulamalı Bilimler } \\
\text { YO }\end{array}$ & 26 \\
\hline $901-1200$ & 13 & 3,4 & Adalet MYO & 7 & 1,3 \\
\hline 1201 ve üzeri & 8 & 2,1 & Uşak MYO & 59 & 15,4 \\
\hline TOPLAM & $\mathbf{3 8 4}$ & $\mathbf{1 0 0}$ & TOPLAM & $\mathbf{3 8 4}$ & $\mathbf{1 0 0}$ \\
\hline
\end{tabular}

Ankete katılanların; \%52,3'ü kız ve \%47,7'si erkek öğrencidir. Çoğunluğu 19-20 yaş grubunda yer almakta $(\% 53,3)$ ve $\% 49,5$ 'i aylık 301-600 TL arasında harçlığa sahiptir. Cevaplayıcıların \%22,4'ü İktisadi ve İdari Bilimler Fakültesi ve \% 21,1’i Fen Edebiyat Fakültesi'nde eğitim görmekte ve büyük çoğunluğu birinci sınıf $(\% 60,4)$ öğrencisidir. İslami İlimler Fakültesi, İletişim Fakültesi, Spor Bilimleri Fakültesi, Ziraat ve Doğa Bilimleri Fakültesi, Uygulamalı Bilimler Yüksekokulu ve Adalet Meslek Yüksekokulu ilk öğrencilerini 2013-2014 Akademik yılında kabul ettiği için cevaplayıcıların büyük çoğunluğunu birinci sınıflar oluşturmaktadır.

\subsubsection{Cevaplayıcıların Algılanan Hizmet Kalitesi İfadelerine Yönelik Tutumları}

Araştırmanın ölçüm güvenilirliğini test etmek için iç tutarlılık değerlendirmesini belirlemek için cronbach $\alpha$ katsayısı yönteminden yararlanılmıştır. Güvenilirlik analizi sonucunda algılanan hizmet kalitesinde güvenilir ve geçerli olmayan soruya rastlanılmamıştır. Algılanan kütüphane hizmet kalitesinin 22 ifadenin Cronbach's Alpha değeri 0,958'dir. Hizmet kalitesinin boyutlarına ait Cronbach's Alpha değerleri Tablo 4'te sunulmuştur. Değerler 0,81'den daha yüksek olduğundan dolayı her ölçekteki soruların içsel uyumunun yüksek olduğu söylenebilir (İslamoğlu ve Alnıaçık, 2013:278). Tablo 2'de algılanan hizmet kalitesi boyutlarına ait ortalama, standart sapma ve Cronbach's Alpha değerleri görülmektedir.

Tablo 2: Cevaplayıcıların Algılanan Hizmet Kalitesi İfadelerine Yönelik Tutumları

\begin{tabular}{|c|c|c|c|}
\hline ALGILANAN HİMET KALİTESİ BOYUTLARI $(\alpha=0,958)$ & Ortalama & $\begin{array}{l}\text { Standart } \\
\text { Sapma }\end{array}$ & $\mathbf{N}$ \\
\hline \multicolumn{4}{|l|}{ FİZIKKSEL ÖZELLİKLER $(\alpha=0,799)$} \\
\hline Modern araç, gereç ve donanıma sahip olması & 4,3105 & 0,6879 & 382 \\
\hline $\begin{array}{l}\text { Fiziksel imkânları (mobilya, aydınlatma, dekor vb.) görsel açıdan çekici } \\
\text { olması }\end{array}$ & 4,2386 & 0,7067 & 381 \\
\hline Çalışanların temiz ve düzgün görünüşlü olması & 4,2755 & 0,7319 & 378 \\
\hline Hizmet verilirken kullanılan malzemelerin modern ve kullanışlı olması & 4,2385 & 0,6889 & 379 \\
\hline TOPLAM & 4,2658 & $\mathbf{0 , 7 0 3 9}$ & \\
\hline \multicolumn{4}{|l|}{ GÜVENILIIRLİK $(\alpha=0,802)$} \\
\hline $\begin{array}{l}\text { Kütüphane bir işi ne zaman yapacağını taahhüt ediyorsa, bu işi o } \\
\text { zamanda gerçekleştirmesi }\end{array}$ & 4,1671 & 0,6652 & 381 \\
\hline $\begin{array}{l}\text { Kütüphane çalışanlarının ögrencilerin bir problemi olduğunda, bunu } \\
\text { çözmek için samimi bir ilgi göstermesi }\end{array}$ & 4,1092 & 0,7551 & 379 \\
\hline Öğrencilere yapılan işlemlerin ilk seferde ve doğru olarak yapılması & 4,2093 & 0,6871 & 380 \\
\hline Kütüphane hizmetlerini söz verdiği zamanda gerçekleştirmesi & 4,0845 & 0,6922 & 389 \\
\hline Öğrencilere ait kayıtların düzenli ve eksiksiz olarak tutulması & 4,1725 & 0,6755 & 380 \\
\hline TOPLAM & 4,1485 & 0,6950 & \\
\hline
\end{tabular}


Optimum Journal of Economics and Management Sciences, Vo1. 3, No. 2- http://dergipark.ulakbim.gov.tr/usakoeyb/ Can and Sezgin - A Survey on the Role of Central Library Perceived Service Quality on Usak University Brand Awareness

\begin{tabular}{|c|c|c|c|}
\hline $\begin{array}{l}\text { Öğrencilere hizmetin tam olarak ne zaman gerçekleştirileceğinin } \\
\text { söylenmesi }\end{array}$ & 4,0928 & 0,7403 & 380 \\
\hline $\begin{array}{l}\text { Kütüphane çalışanlarının hizmetleri mümkün olan en kısa sürede } \\
\text { vermesi }\end{array}$ & 4,0986 & 0,7954 & 381 \\
\hline $\begin{array}{l}\text { Kütüphane çalışanlarının her zaman öğrenciye yardım etmeye istekli } \\
\text { olması }\end{array}$ & 4,1113 & 0,7527 & 379 \\
\hline $\begin{array}{l}\text { Kütüphane çalışanlarının meşgul olsalar dahi öğrencilerin isteklerine } \\
\text { cevap verebilmesi }\end{array}$ & 3,9446 & 0,7485 & 383 \\
\hline TOPLAM & 4,0618 & $\mathbf{0 , 7 5 9 2}$ & \\
\hline \multicolumn{4}{|l|}{ GÜVEN $(\alpha=0,824)$} \\
\hline Kütüphane çalışanlarının davranışlarıyla öğrencilere güven vermesi & 4,2448 & 0,6570 & 384 \\
\hline $\begin{array}{l}\text { Öğrencilerin kütüphane çalışanları ile olan ilişkilerinde kendini güvende } \\
\text { hissetmesi }\end{array}$ & 4,1676 & 0,7417 & 381 \\
\hline Kütüphane çalışanlarının öğrencilere karşı kibar olması & 4,1941 & 0,7209 & 380 \\
\hline $\begin{array}{l}\text { Kütüphane çalışanlarının öğrencilerin sorularına cevap verebilecek } \\
\text { yeterli bilgi seviyesine sahip olması }\end{array}$ & 4,1300 & 0,6882 & 384 \\
\hline TOPLAM & 4,1841 & 0,7019 & \\
\hline \multicolumn{4}{|l|}{ EMPATİ $(\alpha=0,820)$} \\
\hline $\begin{array}{l}\text { Kütüphanede, ihtiyaçları doğrultusunda öğrencilere bireysel ilgi } \\
\text { gösterilmesi }\end{array}$ & 4,0186 & 0,7332 & 384 \\
\hline Kütüphane çalışanlarının öğrencilere kendini özel hissettirmesi & 3,9176 & 0,8296 & 380 \\
\hline $\begin{array}{l}\text { Kütüphane çalışanlarının öğrencilerin menfaatlerini her şeyin üstünde } \\
\text { tutması }\end{array}$ & 3,9697 & 0,8089 & 381 \\
\hline Kütüphanenin öğrenciler için elinden gelenin en iyisini yapmas1 & 4,1296 & 0,7247 & 381 \\
\hline $\begin{array}{l}\text { Kütüphane çalışma saatlerinin öğrenciler için uygun zaman diliminde } \\
\text { olmas1 }\end{array}$ & 4,2222 & 0,7293 & 382 \\
\hline TOPLAM & 4,0515 & 0,7651 & \\
\hline
\end{tabular}

Tablo 2'de görüldüğü üzere fiziksel özellikler boyutunda; kütüphanenin modern araç, gereç ve donanıma sahip olması $(4,3105)$ ve çalışanların temiz ve düzgün görünüşlü olması $(4,2755)$ öne çıkan değişkenleri oluşturmaktadır. Güvenilirlik boyutunda ise, öğrencilere yapılan işlemlerin ilk seferde ve doğru olarak yapılması $(4,2093)$ ve öğrencilere ait kayıtların düzenli ve eksiksiz olarak tutulması $(4,1725)$ değişkenleri öne çıkmaktadır. Yukarıdaki tablodan görüldügü üzere heveslilik boyutu incelendiğinde, kütüphane çalışanlarının her zaman öğrenciye yardım etmeye istekli olması $(4,1113)$ ve kütüphane çalışanlarının hizmetleri mümkün olan en kısa sürede vermesi $(4,0986)$ öne çıkan ifadeleri oluşturmaktadır. Güven boyutunda ise, kütüphane çalışanlarının davranışlarıyla öğrencilere güven vermesi $(4,2448)$ ve kütüphane çalışanlarının öğrencilere karşı kibar olması $(4,1941)$ öne çıkmaktadır. Empati boyutunda algılanan hizmet kalitesi ifadelerinden, kütüphane çalışma saatlerinin öğrenciler için uygun zaman diliminde olması $(4,2222)$ ve kütüphanenin öğrenciler için elinden gelenin en iyisini yapması $(3,1296)$ ifadeleri ortalamalar bakımından ilk sıralarda yer almaktadır.

\subsubsection{Cevaplayıcıların Marka Farkındalığına Yönelik Tutumları}

Marka farkındalığı ölçeğinin güvenilirliğini test etmek için cronbach $\alpha$ katsayısı yönteminden yararlanılmıştır. Güvenilirlik analizi sonucunda marka farkındalığı ölçeğinden "Uşak Üniversitesi Kütüphanesinin üniversite öğrencileri tarafindan bilindiğini düşünüyorum" ve "Uşak Üniversitesi öğrencisi olmadan öncede kütüphane hakkında bilgim vardı" ifadeleri güvenilirlik soru bütün korelasyon katsayısına sahip olmadıkları için ölçekten çıkartılmıştır. Kalan 4 ifadenin Cronbach's Alpha değeri 0,835 olarak hesaplanmıştır. Bu değer ölçekte kalan soruların içsel uyumunun yüksek olduğunu göstermektedir. Tablo 3'de marka farkındalığına ait ifadelerin ortalama, standart sapma ve Cronbach's Alpha değeri sunulmuştur. 
Tablo 3: Cevaplayıcıların Marka Farkındalı̆̆ı İfadelerine Yönelik Tutumları

\begin{tabular}{|c|c|c|c|}
\hline MARKA FARKINDALIĞI İFADELERİ $(\alpha=0,835)$ & Ortalama & $\begin{array}{c}\text { Standart } \\
\text { Sapma }\end{array}$ & $\mathbf{N}$ \\
\hline $\begin{array}{l}\text { Uşak Üniversitesi Kütüphanesi üniversite kütüphaneleri arasında bilinen } \\
\text { bir kütüphanedir. }\end{array}$ & 3,6866 & 1,1483 & 384 \\
\hline Uşak Üniversitesi Kütüphanesi hizmetlerini çok iyi tanıtıyor. & 3,4334 & 1,0854 & 382 \\
\hline Uşak Üniversitesi Kütüphanesinin tanıtımlarından haberdarım. & 3,0934 & 1,2168 & 384 \\
\hline $\begin{array}{l}\text { Uşak Üniversitesi Kütüphanesinin üniversite öğrencileri tarafindan } \\
\text { bilindiğini düşünüyorum. }\end{array}$ & 3,8743 & 1,5738 & 384 \\
\hline $\begin{array}{l}\text { Uşak Üniversitesi Kütüphanesi üniversite kütüphaneleri arasında aklıma } \\
\text { gelen ilk isimdir. }\end{array}$ & 3,0228 & 1,3689 & 380 \\
\hline $\begin{array}{l}\text { Uşak Üniversitesi öğrencisi olmadan öncede kütüphane hakkında bilgim } \\
\text { vardı. }\end{array}$ & 2,5354 & 1,4060 & 382 \\
\hline TOPLAM & 3,2743 & 1,2998 & \\
\hline
\end{tabular}

Tablo 3'de görüldüğü üzere marka farkındalığında, Uşak Üniversitesi Kütüphanesi üniversite kütüphaneleri arasında bilinen bir kütüphanedir $(3,6866)$ ve Uşak Üniversitesi Kütüphanesi hizmetlerini çok iyi tanıtıyor $(3,4334)$ ifadeleri öne çıkan değişkenleri oluşturmaktadır. Uşak Üniversitesi Kütüphanesi öğrenciler tarafından bilindiği ve kütüphanenin hizmetlerinin tanıtımını yeterli seviyede yaptığı söylenebilir.

\subsubsection{Algılanan Hizmet Kalitesi İle Marka Farkındalığı Arasındaki İlişki}

Değişken setleri arasındaki ilişkileri incelemek amacıyla yapılan kanonik korelasyon analizinde algılanan hizmet kalitesi boyutları ile marka farkındalığı değişkenler setinde en düşük değişken sayısı marka farkındalığı setinde (4) setinde olduğu için 4 fonksiyon elde edilmiştir. Tablo 4 'te görüleceği üzere, çalışmada yer alan 4 fonksiyondan 1 tanesi istatistiki açıdan anlamlı bulunmuştur.

Tablo 4: İhtiyacın Ortaya Çıkması Kanonik Korelasyon Analizi Genel Model Uyum Kriterleri

\begin{tabular}{|l|l|l|l|l|l|l|}
\hline $\begin{array}{l}\text { Kanonik } \\
\text { Fonksiyon }\end{array}$ & $\begin{array}{l}\text { Kanonik } \\
\text { Korelasyon } \\
\text { Katsayısı } \\
(\mathbf{R c})\end{array}$ & $\begin{array}{l}\text { Kanonik } \\
\left.\text { Kök (Rc }{ }^{2}\right)\end{array}$ & $\begin{array}{l}\text { Wilk's } \\
\text { Lambda }\end{array}$ & $\begin{array}{l}\text { Ki- } \\
\text { Kare }\end{array}$ & $\begin{array}{l}\text { Serbestlik } \\
\text { Derecesi }\end{array}$ & $\begin{array}{l}\text { İstatistiksel } \\
\text { Anlamlılık }\end{array}$ \\
\hline 1 & 0,405 & 0,164 & 0,811 & 54,048 & 20 & $\mathbf{0 , 0 0 0}$ \\
\hline 2 & 0,127 & 0,016 & 0,970 & 7,843 & 12 & 0,797 \\
\hline 3 & 0,103 & 0,011 & 0,986 & 3,670 & 6 & 0,721 \\
\hline 4 & 0,060 & 0,004 & 0,996 & 0,927 & 2 & 0,629 \\
\hline
\end{tabular}

Ayrıca değişkenler setinin açıklanan varyans oranlarına bakıldığında aynı şekilde birinci fonksiyonların, ilişkiler setinin daha büyük bir kısmını açıkladığı görülmektedir. Bu nedenle araştırmada birinci fonksiyon dikkate alınacaktır. 
Optimum Journal of Economics and Management Sciences, Vo1. 3, No. 2- http://dergipark.ulakbim.gov.tr/usakoeyb/ Can and Sezgin - A Survey on the Role of Central Library Perceived Service Quality on Usak University Brand Awareness

Tablo 5: Algılanan Hizmet Kalitesi ve Marka Farkındalığı Kanonik ve Çapraz Yükler Tablosu

\begin{tabular}{|c|c|c|}
\hline \multirow{2}{*}{ Marka farkındalı̆̆ı İfadeleri } & Kanonik Yükler & $\begin{array}{l}\text { Çapraz } \\
\text { Yükler }\end{array}$ \\
\hline & Birinci Fonksiyon & $\begin{array}{l}\text { Birinci } \\
\text { Fonksiyon }\end{array}$ \\
\hline $\begin{array}{l}\text { Uşak Üniversitesi Kütüphanesi üniversite kütüphaneleri arasında bilinen bir } \\
\text { kütüphanedir. }\end{array}$ & 0,633 & 0,256 \\
\hline Uşak Üniversitesi Kütüphanesi hizmetlerini çok iyi tanıtıyor. & 0,570 & 0,231 \\
\hline Uşak Üniversitesi Kütüphanesinin tanıtımlarından haberdarım. & 0,401 & 0,163 \\
\hline $\begin{array}{l}\text { Uşak Üniversitesi Kütüphanesi üniversite kütüphaneleri arasında aklıma gelen } \\
\text { ilk isimdir. }\end{array}$ & 0,974 & 0,394 \\
\hline Açıklanan Varyans Oranı & 0,541 & \\
\hline \multicolumn{3}{|l|}{ Algılanan Hizmet Kalitesi Boyutları } \\
\hline Fiziksel Özellikler & 0,756 & 0,306 \\
\hline Güvenilirlik & 0,703 & 0,285 \\
\hline Heveslilik & 0,629 & 0,255 \\
\hline Güven & 0,652 & 0,264 \\
\hline Empati & 0,906 & 0,367 \\
\hline Açıklanan Varyans Oranı & 0,075 & \\
\hline
\end{tabular}

Tablo 5'de birinci fonksiyonun kanonik yüklerine bakıldığında birinci sırada Uşak Üniversitesi Kütüphanesi üniversite kütüphaneleri arasında aklıma gelen ilk isimdir $(0,974)$, ikinci sırada Uşak Üniversitesi Kütüphanesi üniversite kütüphaneleri arasında bilinen bir kütüphanedir $(0,633)$ ve üçüncü sırada Uşak Üniversitesi kütüphanesi hizmetlerini çok iyi tanıtıyor $(0,570)$ ifadeleri yer almaktadır. Algılanan hizmet kalitesi boyutlarının kanonik yüklerine bakıldığında ise, en yüksek değerleri empati $(0,906)$, fiziksel özellikler $(0,756)$ ve güvenilirlik $(0,702)$ aldığı görülmektedir. Marka farkındalığında öne çıkan değişkenleri; "üniversite kütüphaneleri arasında akla ilk gelen olması", "kütüphanenin bilinen bir kütüphane olması" ve "kütüphane sunduğu hizmetleri çok iyi tanıtıyor olması" olduğu görülmektedir. Algılanan hizmet kalitesi boyutlarında; "empati", "fiziksel özellikler" ve "güvenilirlik" en yüksek katsayıyı aldığı görülmektedir.

Değişkenler seti arasındaki çapraz ilişkilere bakıldığında, yine en yüksek katsayıları alanların Uşak Üniversitesi Kütüphanesi üniversite kütüphaneleri arasında aklıma gelen ilk isimdir $(0,394)$, ikinci sırada Uşak Üniversitesi Kütüphanesi üniversite kütüphaneleri arasında bilinen bir kütüphanedir $(0,256)$ ve üçüncü sırada Uşak Üniversitesi kütüphanesi hizmetlerini çok iyi tanıtıyor $(0,231)$ ifadeleri olduğu görülmektedir. Algılanan hizmet kalitesi boyutlarının, marka farkındalığı ile çapraz ilişkisinde ise, empati $(0,367)$, fiziksel özellikler $(0,306)$ ve güvenilirlik $(0,285)$ değişkenleri en yüksek değere sahiptir. Bu sonuçlara göre algilanan hizmet kalitesi ile marka farkındalığı arasında anlamlı bir ilişki vardır. $\mathrm{H}_{1}$ hipotezi kabul edilmiştir.

Kanonik korelasyon analizinde elde edilen sonuçların geçerliliğini test etmek amacı ile örnek ikiye bölünerek analiz tekrarlanmış ve benzer sonuçlar elde edilmiştir (Kanonik 
korelasyon katsayısı: 0,516). Daha sonra hassasiyet analizi yapılmış, değişkenlerden bazıları silinerek analiz yinelenmiş ve kanonik korelasyon katsayıları ve değişken katsayılarında değişiklik olmadığı görülmüştür.

\section{SONUÇ}

Uşak Üniversitesi merkez kütüphanesinin kullanıcılarının algılanan hizmet kalitesine yönelik duygu ve düşüncelerini tespit etmek ve kütüphanenin sunduğu hizmetlerin kalitesinin üniversitenin marka farkındalığına etkisindeki rolünü belirlemek amacı taşıyan çalışmada elde edilen sonuçlar şunlardır:

Cevaplayıcılar çoğunlukla kız, 19-20 yaş grubunda, aylık 301-600 TL arası öğrenci harçlığı olan, birinci sınıf ve İktisai ve İdari Bilimler Fakültesi öğrencileridir.

Cevaplayıcılar, kütüphaneyi modern araç ve gerece sahip, çalışanları temiz ve düzgün görünüşlü, fiziksel koşulları (demirbaş, düzen, tasarım vb.) görsel açıdan çekici olarak algılamaktadırlar. Güvenilirlik boyutunda ise, kullanıcılara yapılan işlemlerin ilk seferde ve doğru olarak yapıldığı ve kayıtların düzenli ve eksiksiz olarak tutulduğu belirtilmektedir. Uşak Üniversitesi kütüphanesinin çalışanları, öğrenciye yardım etmekte her zaman istekli davranmakta, talep edilen hizmeti en kısa sürede tamamlamakta ve kullanıcılara sunulacak hizmetin tam zamanı mutlaka söylemektedirler. Ayrıca kütüphane çalışanlarının davranışlarıyla öğrencilere güven verdiği ve kibar davranışlar sergilediği görülmektedir. Katılımcılar, kütüphane çalışma saatlerinin öğrenciler için uygun zaman dilimi içerisinde yer aldığını, üniversite üst yönetiminin kütüphanecilik alanında elinden gelenin en iyisini yapmak için gayretli olduğunu ve ihtiyaçları doğrultusunda bireysel ilgi gösterildiğini belirtmektedir.

Araştırmaya katılanlar, Uşak Üniversitesi kütüphanesinin herkes tarafından bilindiğini, ayrıca diğer üniversite kütüphaneleri arasında tanındığını ve saygı duyulduğunu ve Üniversite üst yönetiminin kütüphanenin tanıtımını ve sunulan hizmetlerin kalitesini arttırmak için gayret gösterdiğini ifade etmektedir.

Yukarıda belirtilen araştırma sonuçları doğrultusunda şu önerilerde bulunulabilir;

- Uşak Üniversitesi kütüphanesinin fiziki görünümünün, kurumun marka farkındalığının oluşturulması ve bunun sonucunda marka değerinin arttırılmasını sağlamak için tanıtım çalışmalarında öne çıkarılması,

- Kütüphane çalışma odalarının ayrılması ve bu çalışma odalarının işletme, kimya, biyoloji gibi ihtisas konularına göre ayrılması ve bu odalarda ilgili bilim alanına ait yayınların yer almas1,

- Kütüphane, öğrenci merkezi gibi öğrencilerin yoğun olarak kullandığı tesislerin üniversitelerin marka farkındalığını arttırmak için hizmet kalitesi araştırmalarına ve kullanıcı memnuniyet anketlerine gereken önemin verilmesi gerekmektedir.

\section{KAYNAKÇA}

Avcı, U. ve Sayılır, A. (2006). Hizmet Kalitesi Çerçevesinde Çalışanların Rolüne ve Yeterliliklerine İlişkin Karşılaştırmalı Bir İnceleme, Ticaret ve Turizm Eğitim Fakültesi Dergisi, Yı1:2006, Sayı:1, s.121-138.

Bebko, C. P. (2000). Service Intangibility and Its Impact on Consumer Expectations of Service Quality, Journal of Service Marketing, Vol:14, No:1, s.9-26.

Bennett, R., ve Ali-Choudhury, R. (2007). Components of the University Brand: an Empirical Study, Proceedings of the 3rd. Annual Colloquium of the Academy of Marketing's Brand, Corporate Identity and Reputation SIG, Brunel University, 12-13 September 2007. 
Berry, L.L. (2000). Cultivating service brand equity. Journal of the Academy of Marketing Science, Vol:28, No:1, p.128-37.

Brookes, M. (2003). Higher Education: Marketing in a Quasi-Commercial Service Industry, International Journal of Nonprofit and Voluntary Sector Marketing, Vol:8, No:2, s.134-42.

Calantone, R.J., Yeniyurt, S., Townsend, J.D. ve Schmidt, J.B. (2010). The Effects of Competition in Short Product Life-Cycle Markets: The Case of Motion Pictures. Journal of Product Innovation Management, 27(3), 349-361.

Demirel, Y., Yoldaş, A. ve Divanoğlu, S. (2009). Algılanan Hizmet Kalitesinin Tatmin, Tavsiye Davranışı ve Tercih Üzerine Etkisi: Sağlık Sektöründe Bir Araştırma, Akademik Bakış Uluslararası Hakemli Sosyal Bilimler E-Dergisi, No:16, s.1-14.

Devebakan, N. (2005). Sağlık İşletmelerinde Algılanan Hizmet Kalitesinin Ölçümünde SERVQUAL Skorlarının Kullanımı ve Özel Altınordu Hastanesi Uygulaması, Dokuz Eylül Üniversitesi Sosyal Bilimler Enstitüsü Dergisi, Cilt:5, Sayı:1, s.38-54.

Fuchs, C. ve Schreier, M. (2011). Customer Empowerment in New Product Development. Journal of Product Innovation Management, Vol.28, No.1, s.17-32.

Grönroos, C. (2000). Service Management and Marketing, John Wiley\&Sons Ltd, UK.

Güzel, D. ve Kotan, G. (2013). Kütüphanelerde Hizmet Kalitesi Ölçümü Atatürk Üniversitesi Merkezi Kütüphanesi’nde Bir Uygulama, Kahramanmaraş Sütçü İmam Üniversitesi İ̈BF Dergisi, Cilt:3, Sayı:2, s.11-24.

Hacıefendioğlu, Ş. ve Koç, Ü. (2009). Hizmet Kalitesi Algılamalarının Müşteri Bağlılığına Etkisi ve Fast-Food Sektöründe Bir Araştırma, Kocaeli Üniversitesi Sosyal Bilimler Enstitüsü Dergisi, Cilt:17, No:2, s.146-167.

İslamoğlu, A. H. ve Alnıaçık, Ü. (2013). Sosyal Bilimlerde Araştırma Yöntemleri, Geliştirilmiş ve Gözden Geçirilmiş 3. Bask1, Beta Yayınevi:İstanbul.

Jamali, R. ve Tooranloo, H.S. (2009). Prioritizing Academic Library Service Quality Indicators Using Fuzzy Approach Case Study: Libraries of Ferdowsi University, Library Management, Vol:30, No:4/5, s.319-333.

Kang, G. (2006). The Hierarchical Structure of Service Quality: Integration of Technical and Functional Quality, Managing Service Quality, Vol:16, No:1, s.37-50.

Kuriloff A., Hohn, M.H. ve Douglas, C. (1993). Starting and Managing The Small Business, Singapore: Mc GrawHill Edition.

Liu, Y. ve Hua, J.S. (2008). "An Empirical Research on the Forming of Students' Loyalty to University Brand from the Brand Community Point of View", International Workshop on Education Technology and Training, Shanghai, China.

Mei, A. W. O., Dean, A. M. ve White, C.J. (1999). Analysing Service Quality in the Hospitality Industry, Managing Service Quality, Vol:9, No:2, s.136-143.

Meng, J., Summey, J.H., Herndon, N.C. ve Kenneth, K.K. (2009). Some Retail Service Quality Expectations of Chinese Shoppers, International Journal of Market Research, Vol:51,No:6,s.773-796.

Morgan, N.A. ve Vorhies, D.W. (2001). Product Quality Alignment And Business Unit Performance. Journal of Product Innovation Management, Vol.18, No.6, s.396-407.

Naik, C.N.K., Gantasala, S.B. ve Prabhakar, G.V. (2010). Service Quality (Servqual) And Its Efect On Customer Satisfaction In Retailing, European Journal Of Social Sciences, Vol:16, No:2, s.231.

Nakip, M., Varinli, İ. ve Güllü, K. (2006). Süpermarketlerde Çalışanların ve Tüketicilerin Hizmet Kalitesi Beklentilerinin ve Algılamalarının Karşılaştırılmasına Yönelik Bir Araştırma, Atatürk Üniversitesi İktisadi ve İdari Bilimler Dergisi, Cilt: 20 Eylül 2006 Sayı: 2,s.373-386. 
Odabaşı, Y. (2003). Satışta ve Pazarlamada Müşteri Illişkileri Yönetimi, Sistem Yayıncılık, ANKARA.

Oliver, R. (1999). Whence Consumer Loyalty?, Journal of Marketing, Vol:63, s.33-44.

Parasuraman, A. (2002). Service Quality and Productivity: A Synergistic Perspective, Managing Service Quality, Vol:12, No:1, s.6-9.

Parasuraman, A., Zeithaml, V.A., Berry, L.L. (2008). A Multiple-Item Scale for Measuring Consumer Perceptions of Service Quality, Journal of Retailing, Vol:64, No:1, s.10-25.

Sahney, S., Banwet, D.K. ve Karunes, S. (2004). A SERVQUAL and QFD Approach to Total Quality Education, International Journal of Productivity and Performance Management, Vol:53, No:2, s.143-166.

Schmidt, G.M. ve Druehl, C.T. (2008). When Is a Disruptive Innovation Disruptive?. Journal of Product Innovation Management, Vol.25, No.4, s.347-369.

Sharma, J.C. (2001). Total Quality Management in Library and Information Services, in Dhawan, S.M. (Ed.), Quest for Quality, Indian Library Association, The New Challenge of Branding Buy-in, New Delhi, s.166-171.

Stamp, R. (2004). Education News, Winter, Euro RSG.7.

Tekingündüz, S. (2010). Kamu Hastaneleri Kalite Çalışmalarının Değerlendirilmesi, T.C. Sağlık Bakanlığı Tedavi Hizmetleri Genel Müdürlüğü, II. Uluslararası Sağlıkta Performans ve Kalite Kongresi Bildiriler Kitabı, Cilt:1, s.541548 .

Tsaur, S.H. ve Lin, Y.C. (2004). Promoting Service Quality In Tourist Hotels: The Role of HRM Practices and Service Behavior, Tourism Management, Vol:25, No:4, s.471-481.

Uyguç, N. (1998). Hizmet Sektöründe Kalite Yönetimi, Dokuz Eylül Yayınları, İzmir.

Yanık, A., Dinçel, G., Yıldız, F. ve Karacan, S. (2012). Muhasebe Meslek Mensuplarının İdeal Hizmet ve Mevcut Hizmet Kalitesi Algılarının Servqual Modeli İle Değerlendirilmesi, Mustafa Kemal Üniversitesi Sosyal Bilimler Enstitüsü Dergisi, Cilt:9, Say1:20, s.593-604.

Yapraklı, Ş. ve Sağlık, E. (2010). Hizmet İşletmelerinde Rekabet Aracı Olarak Hizmet Kalitesi ve İlişki Kalitesi: Konaklama İşletmelerinde Bir Uygulama, Öneri, Cilt:9, Sayı:34, s.71-85.

Yoo, B. ve Donthu, N. (2001). Developing and Validating a Multidimensional Consumer-Based Brand Equity Scale. Journal of Business Research. Vol:52, No:1, p.1-14.

Zengin, E. ve Erdal, A. (2005). Hizmet Sektöründe Toplam Kalite Yönetimi, Qafqaz Üniversitesi Dergisi, Ocak 2005, s.4. 